\title{
TANGGUNG JAWAB PENYEDIA JASA PT. TIKI JALUR NUGRAHA EKAKURIR (JNE) ATAS KETERLAMBATAN BARANG DITINJAU DARI HUKUM PERLINDUNGAN KONSUMEN (STUDI PADA PT TIKI JNE CABANG BURUAN GIANYAR)*
}

\author{
Oleh : \\ Ketut Braditya Pradnyana Putra** \\ Dewa Gde Rudy ${ }^{* * *}$ \\ Program Kekhususan Hukum Bisnis Fakultas Hukum \\ Universitas Udayana
}

\begin{abstract}
ABSTRAK
Semakin canggihnya teknologi sangat mempengauhi pola hidup manusia. Seperti keberadaan perusahaan pengiriman barang mempermudah pekerjaan manusia. Namun dalam kenyataannya di masyarakat tidak selalu berjalan dengan lancar dalam pelayanan dari penyedia jasa pengiriman barang, yang salah satunya yaitu keterlambatan sampainya barang ke tempat tujuan yang tidak dengan sesuai yang dijanjikan oleh pihak perusahaan penyedia jasa pengiriman barang. Hal itu merupakan suatu wanprestasi karena perusahaan penyedia jasa pengiriman barang tidak memenuhi prestasi yang telah dijanjikan kepada konsumen pengguna jasa. Penulisan ini mengangkat permasalahan mengenai tanggung jawab penyedia jasa pengiriman barang atas keterlambatan barang sampai di tempat tujuan dan upaya pencegahan terhadap keterlambatan layanan pengiriman barang PT TIKI JNE cabang buruan Gianyar atas keterlambatan sampainya barang ditempat tujuan. Penulisan ini menggunakan metode penelitian hukum empiris, yang artinya hasil penelitian didapat melalui wawancara atau penelitian yang secara langsung ke lapangan guna mendapatkan kebenaran yang akurat, Berdasarkan hasil yang didapat, maka perusahaan penyedia jasa pengiriman barang kalau terbukti melakukan wanpretasi maka harus memberikan ganti rugi terhadap konsumen sebagaimana

\footnotetext{
* Jurnal Hukum di Luar Ringkasan Skripsi, "Tanggung Jawab Penyedia Jasa PT. Tiki Jalur Nugraha Ekakurir (JNE) Atas Keterlambatan Barang Ditinjau Dari Hukum Perlindungan Konsumen (Studi Pada PT Tiki JNE Cabang Buruan Gianyar".

${ }^{* *}$ Ketut Braditya Pradnyana Putra, Adalah Mahasiswa Fakultas Hukum Universitas Udayana.

*** Dewa Gde Rudy, Adalah Dosen Pengajar Bidang Hukum Bisnis Fakultas Hukum Universitas Udayana.
} 
telah diatur dalam perundang-undangan.Upaya pencegahan terhadap keterlambatan layanan pengiriman barang PT TIKI JNE cabang buruan Gianyar dimuali dengan 4 proses pola oprasional yakni collecting, prosessing, transporting, delivery

\title{
Kata Kunci : Tanggung Jawab, Perlindungan Konsumen, Keterlambatan.
}

\begin{abstract}
The more sophisticated technology really influences the pattern of human life. As the existence of a freight forwarding company facilitates human work. But in reality the community does not always run smoothly in the service of the freight forwarder, one of which is the delay in arriving at the destination which is not as promised by the freight forwarding company. This is a default because the shipping service provider company does not meet the promised promises to consumers of service users. This writing raised the issue of the responsibility of the shipping service provider for the delay of the goods arrived at their destination and the prevention of delays in the delivery service of PT TIKI JNE Gianyar's hunting branch for the delay in arriving at the destination. This writing uses empirical legal research methods, which means that the results of research are obtained through interviews or research directly to the field in order to obtain accurate truths. Based on the results obtained, the freight forwarding company if proven to interpret it must provide compensation to consumers. as regulated in the legislation. Efforts to prevent delays in the delivery of goods services of PT TIKI JNE Gianyar prey branch are started with 4 operational processes, namely collecting, processing, transporting, delivery.
\end{abstract}

\section{Keywords: Responsibility, Consumer Protection, Delay.}

\section{PENDAHULUAN}

\subsection{Latar Belakang}

Dengan adanya perusahaan penyedia jasa pengiriman barang tentu saja akan sangat memudahkan pekerjaan manusia, yang dikarenakan oleh faktor efisiensi yang ditawarkan pihak perusahaan penyedia jasa pengiriman barang seperti efektiv segi waktu dan biaya.

Walaupun dengan adanya perusahaan penyedia jasa pengiriman barang yang mempermudahkan dalam pekerjaan manusia. Namun dalam kenyataannya di masyarakat tidak selalu 
berjalan dengan lancar dalam pelayanan dari penyedia jasa pengiriman barang, salah satunya keterlambatan sampainya barang ketempat tujuan yang dimana tidak sesuai yang dijanjikan oleh pihak perusahaan penyedia jasa pengiriman barang, dimana pihak penyedia jasa tersebut telah memberikan jenis pilihan yang akan digunakan konsumen namun tidak sesuai dengan layanan yang diberikan. Hal tersebut merupakan wanprestasi karena perusahaan penyedia jasa pengiriman barang tidak memenuhi prestasi yang telah dijanjikan kepada konsumen pengguna jasa.

Dengan adanya keterlambatan tersebut pengguna layanan jasa pengiriman barang akan merasa dirugikan karena pihaknya telah membayar sejumlah uang tertentu untuk mendapatkan pelayanan jasa yang seharusnya ia dapatkan. Oleh karena itu, pihak konsumen berhak mendapat perlindungan hukum ketika pengiriman barang tersebut mengalami keterlambatan.

PT. TIKI Jalur Nugraha Ekakurir (JNE) Cabang buruan Gianyar merupakan perusahaan penyedia jasa pengangkutan/pengiriman barang menyelenggarakan usahanya dengan cara memberikan layanan pengiriman barang ke tempat tujuan dengan selamat dan tepat waktu tergantung dari pilihan layanan yang digunakan. Namun, dalam suatu proses pengiriman barang dapat terjadi keterlambatan, kerusakan atau bahkan kehilangan barang kiriman, yang mana dapat diakibatkan oleh kesalahan/kelalaian PT. JNE sebagai pihak pengangkut.

Praktik bisnis seperti kontrak penitipan kendaraan, kontrak beli sewa, kontrak jasa pengiriman barang dan lain-lain, realitasnya belum mendapat pengaturan khusus dalam bentuk peraturan perundang-undangan (meski secara formal terdapat regulasi), sehingga untuk hal-hal spesifik mengenai hak dan kewajiban diserahkan kepada "persetujuan" para pihak. Akibatnya 
adalah menimbulkan keresahan karena belum terpenuhinya perlindungan akan kepastian hukum yang mengatur hubungan hukum diantara para pelaku bisnis, yang dengan sendirinya akan berdampak pada kepentingan masyarakat umum. ${ }^{1}$

Masalah keterlambatan dan kerusakan pengiriman barang yang dipersalahkan adalah bukan hanya tanggung jawab dari pihak PT. TIKI JNE yang tidak terlepas dari melakukan kesalahan baik sebelum atau sesudah barang tersebut diangkut oleh pengangkut. Oleh sebab itu, penting sekiranya untuk mengetahui bagaimana tanggung jawab PT. TIKI JNE dan perlindungan hukum bagi masyarakat yang mengunakan layanan pengiriman barang melalui PT. TIKI JNE, sehingga konsumen mengetahui haknya sebagai konsumen yang telah membayar dan mempercayakan barang yang ingin dikirim melalu jasa pengiriman.

\subsection{Rumusan Masalah}

1. Bagaimana pertanggungjawaban penyedia jasa PT TIKI JNE cabang buruan Gianyar atas keterlambatan sampainya barang ditempat tujuan?

2. Bagaimana upaya pencegahan terhadap keterlambatan layanan pengiriman barang PT TIKI JNE cabang buruan Gianyar atas keterlambatan sampainya barang ditempat tujuan?

\subsection{Tujuan Penulisan}

Penulisan ini bertujuan untuk memahami tentang tanggung jawab penyedia jasa pengiriman barang atas keterlambatan sampainya barang ditempat tujuan, dan untuk mengetahui upaya

1 Ronald Saija. 2016, Penyalahgunaan Keadaan Oleh Negara Dalam Praktik Perjanjian Pada Kajian Hukum Privat. Kertha Patrika, vol. 38, n. 3, desember.2016.h.2,https://ojs.unud.ac.id/index.php/kerthapatrika/article/vie w/30080.Diakses tanggal 07 june 2019. 
pencegahan terhadap keterlambatan layanan pengiriman barang PT TIKI JNE cabang buruan Gianyar atas keterlambatan sampainya barang ditempat tujuan.

\section{ISI MAKALAH}

\subsection{Metode}

Metode penelitian adalah cara-cara yang ditempuh untuk memahami objek yang menjadi sasaran penelitian guna mencari dan mendapatkan suatu kebenaran hukum. Adapun jenis penelitian yang digunakan dalam penelitian ini adalah penelitian hukum empiris. Penelitian hukum empiris merupakan suatu penelitian yang dilakukan dengan cara memadukan data sekunder dan data primer yang didapat melalui wawancara atau penelitian yang secara langsung ke lapangan guna mendapatkan kebenaran yang akurat. ${ }^{2}$

Penelitian hukum pada dasarnya merupakan suatu kegiatan ilmiah yang didasarkan pada metode, sistematika dan pemikiran tertentu, yang bertujuan untuk mempelajari satu atau beberapa gejala hukum tertentu dengan jalan menganalisa. Maka juga diadakan pemeriksaan yang mendalam terhadap fakta hukum tersebut untuk kemudian mengusahakan suatu pemecahan atas permasalahan-permasalahan yang timbul di dalam gejala bersangkutan. ${ }^{3}$

\footnotetext{
${ }^{2}$ Soerjono Soekanto, 2007, Pengantar Penelitian Hukum, Universitas Indonesia, Jakarta, h.51

3 Bambang Sunggono, 2015, “Metode Penelitian Hukum”, PT Raja Grafindo Persada, Jakarta, h.38
} 


\subsection{Hasil dan Pembahasan}

\subsubsection{Pertanggungjawaban PT TIKI JNE cabang buruan Gianyar Atas Keterlambatan Barang di Tempat Tujuan}

Pengiriman barang terjadi karena adanya suatu permintaan yang dilakukan oleh pihak pengirim kepada pihak pengangkut. Peristiwa ini didasari oleh adanya suatu perjanjian antara pihak yakni pihak pengangkut dan pihak pengirim. Dalam setiap perjanjian bagi kedua belah pihak akan mempunyai hak dan kewajiban antara lain pihak konsumen maupun pelaku usaha/penyedia jasa. Maka, konsumen dan pelaku usaha harus memenuhi hak dan kewajiban tersebut agar suatu perjanjian dapat terlaksana dengan baik. Dalam Undang-udang Nomor 8 Tahun 1999 tentang Perlindungan Konsumen (UUPK) Pasal 4 sampai dengan Pasal 7 telah mengatur hak dan kewajiban bagi konsumen dan pelaku usaha.

Kemudian pada bagian kedua, Bab III, Undang-Undang Nomor 8 Tahun 1999 tentang Perlindungan Konsumen, hak pengusaha diatur dalam Pasal 6 dan kewajiban pengusaha diatur dalam Pasal 7. Adapun hak pengusaha yaitu, hak menerima pembayaran, hak untuk mendapatkan perlindungan hukum, dan hak untuk mendapatkan pembelaan diri, sedangkan kewajibannya yaitu, beritikad baik dalam melakukan kegiatan, memberikan informasi yang benar, melayani konsumen dengan baik, dan memberi kompensasi ganti rugi Ketentuan Pasal 6 dan Pasal 7 Undang-Undang Nomor 8 Tahun 1999 ini sebagai hak dan kewajiban pelaku usaha yang merupakan intimoni (memiliki makna sama) dalam 
hukum, sehingga kewajiban pelaku usaha dapat dilihat sebagai hak konsumen ${ }^{4}$

Berikut merupakan sebab-sebab keterlambatan menurut Bapak Gede Panca, Penanggung jawab PT JNE Cabang buruan Gianyar, antara lain :

1. Kurangnya jumlah petugas, jumlah petugas pengirim barang tidak seimbang dengan peningkatan frekuensi dan kuantitas barang yang harus dikirimkan, sehingga menyebabkan keterlambatan pengiriman barang ke tempat tujuan.

2. Masa-masa ramai, dimana kesibukan yang terjadi dalam aktivitas melebihi biasanya. Ada waktu-waktu tertentu, dimana tiba saatnya pengiriman barang akan meningkat dengan drastis

3. Alamat tidak lengkap, hal ini kadang terjadi, dimana ada konsumen yang mencantumkan alamat yang kurang lengkap, atau justru salah menuliskan alamatnya.

4. Nama yang tidak sesuai, ada kecenderungan beberapa konsumen dikenal dengan nama yang berbeda di tempat tinggalnya yang dapat menyebabkan bingungnya petugas pengirim barang.

5. Tidak mencantumkan nomor telepon, nomor telepon sangat penting untuk mengkonfirmasi pada penerima barang saat petugas pengiriman barang akan mendatangi lokasi.

\footnotetext{
${ }^{4}$ Anak Agung Adi Lestari. 2016, "Perjanjian Baku Dalam Jual Beli Kredit Sepeda Motor Ditinjau Dari Undang-Undang Nomor 8 Tahun 1999". Jurnal Magister Hukum Udayana (Udayana Master Law Journal)h. 9 , vol. 5, no. 2, p. 337 - 352, july 2016. https://ojs.unud.ac.id/index.php/jmhu/article/view/22445, Diakses tanggal 07 juni 2019.
} 
6. Force majeure menurut kamus hukum adalah keadaan dimana seorang debitur terhalang untuk melaksanakan prestasinya, karena keadaan atau peristiwa tidak terduga pada saat dibuatnya kontrak, keadaan atau peristiwa tersebut tidak dapat dipertanggungjawabkan kepada debitur.9kondisi atau sebab diluar kemampuan manusia misalnya karena cuaca, bencara alam, angin puting beliung, hujan badai, atau petir yang menyambar dan perang huruhara, pergolakan sipil dan sejenisnya.

Namun penyebab terjadinya keterlambatan terjadi pada karena kurangnya jumlah petugas, jumlah petugas pengirim barang tidak seimbang dengan peningkatan frekuensi dan kuantitas barang yang harus dikirimkan, sehingga menyebabkan keterlambatan pengiriman barang ke tempat tujuan dan pada saat masa-masa ramai, dimana kesibukan yang terjadi dalam aktivitas melebihi biasanya. Ada waktu-waktu tertentu, dimana tiba saatnya pengiriman barang akan meningkat dengan drastis.

Pihaknya menyebutkan bentuk tanggung jawab dari PT TIKI JNE adalah dengan memberikan ganti rugi dapat berupa pengembalian uang atau penggantian barang dan/atau jasa yang sejenis atau setara nilainya, yang sesuai dengan ketentuan peraturan perundangundangan yang berlaku. UUPK telah cukup mengatur mengenai tanggung jawab pelaku usaha sekaligus penyedia layanan jasa yang dalam hal ini adalah PT.TIKI JNE cabang buruan Gianyar atas terjadinya keterlambatan layanan pengiriman barang milik konsumen yang diakibatkan karena kelalaian dari pihaknya. Konsumen yang mengalami kerugian dapat mempergunakan hal tersebut sebagai dasar untuk 
menuntut hak-hak yang harus diperolehnya. Tanggung jawab PT TIKI JNE dapat dikategorikan kedalam prinsip praduga untuk selalu bertanggung jawab dan prinsip tanggung jawab dengan pembatasan.

Timbulnya tanggung jawab atas keterlambatan sampainya barang di tempat tujuan yaitu karena pihak pengangkut atau penyedia jasa pengiriman barang melaksanakan tugasnya namun tidak tepat waktu sehingga menimbulkan kerugian kepada pihak konsumen. Karena terlambat memenuhi suatu prestasi maka pihak pelaku usaha sudah tidak dapat dikatakan wanprestasi yang mengakibatkan pihak penyedia jasa pengiriman barang harus bertanggung jawab dengan memberikan ganti kerugian terhadap konsumen.

Dalam hukum perlindungan konsumen prinsip-prinsip tanggung jawab merupakan hal yang penting. Pada kasus-kasus pelanggaran hak-hak konsumen memerlukan kehati-hatian dalam menganalisa kasus tersebut, seperti halnya siapa yang harus bertanggung jawab dan seberapa besar tanggung jawab yang didapat dibebankan kepada pihak-pihak terkait,

Pada dasarnya pengangkut bertanggung jawab atas musnah, hilang atau rusaknya barang yang diangkut sejak barang tersebut diterima oleh pengangkut dari pihak pengirim/pemilik barang, merupakan suatu konsekuensi perjanjian pengangkutan yang telah diadakan antara pengangkut dengan penumpang atau pemilik barang atau pengirim barang, dimana sesuai dengan Pasal 40 UU No. 17 Tahun 2008 Tentang Pelayaran.

Apabila pihak penyedia jasa pengiriman barang atau orang yang mengangkut (pengangkut) tidak menjalankan kewajiban sebagaimana mestinya. Maka, pihak penyedia jasa pengiriman barang wajib bertanggung jawab, artinya pihak penyedia jasa 
pengirim barang harus menanggung semua akibat yang timbul dari perbuatan penyelenggaraan dari pengangkutan.

\subsubsection{Upaya pencegahan terhadap keterlambatan pengiriman barang atas keterlambatan sampainya barang ditempat tujuan pada PT TIKI JNE cabang buruan Gianyar}

Apabila tuntutan ganti kerugian didasarkan pada wanprestasi, maka terlebih dahulu tergugat dengan penggugat (produsen dengan konsumen) terikat suatu perjanjian. ${ }^{5}$ Tanggung jawab penyedia usaha diatur dalam pada Pasal 19 Undang-undang Nomor 8 Tahun 1999 tentang Perlindungan Konsumen tentang Tanggung Jawab penyedia usaha menyebutkan bahwa "Pelaku usaha bertanggung jawab memberikan ganti rugi atas kerusakan, pencemaran, dan / atau kerugian konsumen akibat mengkonsumsi barang dan /atau jasa yang dihasilkan atau diperdagangkan". Keterlambatan barang sampai tempat tujuan yang diakibatkan kelalaian dari pihak penyedia jasa pengiriman barang, maka dari itu pihak penyedia jasa pengiriman barang harus memenuhi kewajibannya untuk memberikan kompensasi atau ganti rugi, sebagimana telah diatur pada Pasal 7 Undang-undang Nomor 8 Tahun 1999 tentang Perlindungan Konsumen, khususnya huruf $\mathrm{f}$ yang menyatakan "Memberi kompensasi, ganti rugi dan/atau jasa yang diterima atau dimanfaatkan tidak sesuai dengan perjanjian".

Maka konsumen memiliki hak sebagaimana telah diatur pada Undang-udang Nomor 8 Tahun 1999 tentang Perlindungan Konsumen khususnya pada Pasal 4 huruf h yang menyatakan "hak untuk mendapatkan kompensasi, gantu rugi dan/atau penggantian, apabila barang dan/jasa yang diterima tidak sesuai dengan perjanjian atau tidak sebagimana mestinya". Konsumen

${ }^{5}$ Ahmadi Miru \& Sutarman Yodo, 2015, "Hukum Perlindunga Konsumen", PT Raja Grafindo, Jakarta, h. 131. 
berhak mendapatkan ganti kerugian yang pantas jika konsumen merasakan, kuantitas dan kualitas barang dan/atau jasa yang dikonsumsinya tidak sesuai dengan nilai tukar yang diberikannya. ${ }^{6}$

Guna mencegah terjadinya sengketa pada konsumen, PT TIKI JNE mengupayakan pencegahan terlambatnya barang, Menurut bapak Gede Panca, Kepala Penanggung jawab PT TIKI JNE cabang buruan Gianyar, telah melakukan upaya-upaya mencegah timbulnya kerugian bagi konsumen akibat keterlambatan pengiriman barang dengan menekankan kepada empat proses pola oprasional yang dikerjakan oleh para karyawan antara lain :

\section{Collecting}

Tahap collecting dilakukan pada loket tempat pertama yang didatangi oleh konsumen, karyawan/ petugas yang bekerja pada loket memastikan bahwa barang yang akan dikirim telah memenuhi SOP (Standar Oprasional Prosedur) ketentuan yang ditetapkan (untuk mengetahui jenis kiriman yang akan dilakuan oleh konsumen), kemudian Proses Prohibited dimana dihususkan untuk kiriman yang disertai izin atau dokumen resmi oleh pemerintah harus lengkap (exspor maupun impor), penulisan alamat dipastikan lengkap dan jelas disertakan kode pos dan nomor handphone yang dapat dihubungi baik pengirim maupun penerima, format penulisan juga dipastikan benar pada amplop kiriman dan dokumen kiriman, dan yang terakhir saat melakukan input pada system

\footnotetext{
${ }^{6}$ Cecilina Tri Siwi Kristiyanti, op cit, h.37.
} 
data harus dipastikan sama agar meminimalisisr terjadinya kesalahan pada proses selanjutnya.

2. Processing

Pada tahap processing disini ditekankan kepada karyawan/ petugas PT TIKI JNE dalam mensortir atau memilah kiriman sesuai dengan tujuan baik dalam negeri atau luar negeri dan sesuai dengan jenis kiriman baik ekspress, kilat, maupun biasa.

\section{Transporting}

Pada tahap transporting karyawan dari PT TIKI JNE dituntut untuk melakukan pengiriman sesuai dengan jadwal atau tepat waktu serta memastikan jumlah dari item atau barang yang akan di angkut.

4. Delivery

Pada tahap delivery karyawan dari PT TIKI JNE diwajibkan untuk memperhatikan SWP (Standard Waktu Pengiriman) agar tidak terjadi kekacauan antara paket ekspress, kilat, maupun biasa. Meyakinkan setiap kiriman yang datang diantar pada kesempatan pertama dan tidak menunda-nunda. Setelah melakunan pengiriman para karyawan PT TIKI JNE yang bertugas pada bagian delivery harus mengupdate mengenai status dari barang kiriman secara berkala sehingga konsumen dapat mengecek secara langusng keberadaan barang mereka pada website atau halaman resmi PT TIKI JNE yakni (www.jne.co.id). Hal diatas merupakan upaya yang dilakukan oleh PT TIKI JNE dalam hal meminimalisir timbulnya kerugian baik dari pihak konsumen maupun pihak PT TIKI JNE sendiri, dan untuk 
menjaga kepercayaan dari konsumen pengguna jasa layanan.

\section{PENUTUP}

\subsection{Kesimpulan}

Berdasarkan analisis dan pembahasan diatas, dapat diambil kesimpulan yaitu :

2.1.1. Penyebab terjadinya keterlambatan layanan pengiriman barang PT TIKI JNE cabang buruan Gianyar disebabkan kurangnya jumlah petugas dan terjadi pada masa-masa ramai, jumlah petugas pengirim barang tidak seimbang dengan peningkatan frekuensi barang yang harus dikirimkan, sehingga menyebabkan keterlambatan pengiriman barang ke tempat tujuan. Adapun bentuk tanggung jawab PT TIKI JNE dalam melakukan kegiatan usahanya di bidang layanan jasa pengiriman barang terhadap konsumenya berupa pemberian ganti rugi. Berdasarkan dari Pasal 4 huruf g dan pasal 7 huruf g Undang-Undang Nomor 8 Tahun 1999 tentang Perlindungan Konsumen perusahaan penyedia layanan jasa pengiriman barang dapat dimintai kompensasi, ganti rugi dan/atau penggantian.

2.1.2. Upaya pencegahan terhadap keterlambatan layanan pengiriman barang PT TIKI JNE cabang buruan Gianyar dimuali dengan 4 proses pola oprasional yakni collecting, prosessing, transporting, delivery serta mengawasi kinerja para pegawai secara ketat guna mencegah terjadinya keterlambatan atau kerusakan barang. 


\subsection{Saran}

2.2.1. PT. TIKI Jalur Nugraha Ekakurir (JNE) seharusnya merekrut anggota tambahan atau pekerja paruh waktu pada masa-masa ramai guna membantu petugas dalam proses pengiriman barang sehingga dapat mencegah terjadinya keterlambatan barang ke tempat tujuan.

2.2.2. Sebaiknya penyedia jasa pengiriman memperhatikan kualitas pegawai dan mengawasi pengiriman barang sesuai dengan perjanjian yang disepekati sebelumnya, guna tidak mengecewakan konsumen yang berdampak pada kerugian.

\section{DAFTAR PUSTAKA}

\section{Buku}

Fajar, Mukti dan Yulianto Achmad, 2015, Dualisme Penelitian Hukum Normatif \& Empiris, cet. III, Pustaka Pelajar, Yogyakarta.

Peter Mahmud Marzuki, 2016, Penelitian Hukum, cet. XII, Kencana, Jakarta.

Sunggono, Bambang, 2015, Metode Penelitian Hukum, cet. XV, PT Raja Grafindo Persada, Jakarta.

Miru, Ahmadi \& Yodo, Sutarman, 2015, Hukum Perlindungan Konsumen, PT RajaGrafindo, Jakarta.

Kristiyanti, Celina Tri Siwi , 2017, Hukum Perlindungan Konsumen, cet. IV, Sinar Grafika, Jakarta.

Rudy, Dewa Gde et. Al., Buku Ajar Hukum Perlindungan Konsumen, Fakultas Hukum Unversitas Udayana, Denpasar.

Herlina, Rita, 2017, Tanggung Jawab Negara Terhadap Perlindungan Konsumen Ditinjau dari Hukum Perdata, 
Puslitbang Hukum dan Peradilan Mahkamah Agung RI, Jakarta

\section{Jurnal}

Saija, Ronald. 2016, "Penyalahgunaan Keadaan Oleh Negara Dalam Praktik Perjanjian Pada Kajian Hukum Privat”. Kertha Patrika, vol. 38, no. 3, desember. 2016, https://ojs.unud.ac.id/index.php/kerthapatrika/article/vie $\underline{\mathrm{w} / 30080}$ diakes pada tanggal 07 Juni 2019.

Adi Lestari, Anak Agung, 2016, "Perjanjian Baku Dalam Jual Beli Kredit Sepeda Motor Ditinjau Dari Undang-Undang Nomor 8 Tahun 1999". Jurnal Magister Hukum Udayana (Udayana Master Law Journal), vol. 5, no. 2, p. 337 - 352, july 2016, https://ojs.unud.ac.id/index.php/jmhu/article/view/22445 diakses pada tanggal 07 Juni 2019.

\section{Peraturan Perundang-Undangan}

Indonesia, Undang-Undang Nomor 8 Tahun 1999 tentang Perlindungan Konsumen (Lembaran Negara Republik Indonesia Tahun 1999 Nomor 42).

Indonesia, Undang-Undang Nomor 30 Tahun 1999 tentang Arbitrase dan Alternatif Penyelesaian Sengketa (Lembaran Negara Republik Indonesia Tahun 1999 Nomor 138) 